\title{
THE GENDER OF THE HEROES, STORYTELLERS AND COLLECTORS OF ESTONIAN FAIRY TALES
}

\section{Risto Järv}

\begin{abstract}
The article concerns the gender of fairy-tale (ATU 300-749) tellers according to Estonian archival records (5550 units) and the different combinations of the genders of the recorders, the tellers and the main characters. The high and low tides of recording fairy-tales for the archive are analysed, as well as possible reasons for the tides. It appears there has been a change in the 1920s regarding fairy-tales - the earlier tales have been collected mostly from men, the later ones - from women.

Another point of discussion is masculine and feminine plots. The tendency noted also by e.g. B. Holbek is significant, towards men preferring tales with male heroes while women tell tales with both male and female heroes. Based on the Estonian fairy tales corpus, there is an observable shift in the 20th century of masculine fairy tales having become more popular among women; some reasons for this tendency are elaborated.

Keywords: tales of magic, fairy tales, male and female storytellers, masculine and feminine plots, gender studies.
\end{abstract}

In folklore, as in many other fields, gender issues have been the focus of numerous scholars' attention for some decades already and quite often it has been suggested that earlier understandings of folklore should be revised in this light. Indeed, the gender stereotypes reflected in folktales do not meet contemporary requirements for equality: for instance, it has been noticed about Finnish folktales that there are but few active woman heroes and, in addition, the tales usually represent women in the role of passive objects (cf Apo 1990: 24). This situation has inspired several authors to retell traditional folktales. Relevant examples are offered in an analysis of novels and films that remind of the plot of the Bluebeard tale (ATU 312) and adopt the woman's point of view (see Lovell-Smith 1999). Even such a thoroughly masculine tale as "The Dragon Slayer" (ATU 300) has been rewritten - the fearless princess kills a huge dragon, letting men do away with the remains (Stone 1975: 50).

However, what seems more rewarding than rewriting earlier folklore is revising the attitudes expressed in treatments of folklore. Even regarding the Aarne-Thompson type-index (that pre- 
sumably presents the material in an impartial manner) Tuborg Lundell has said that the names for tale types do not adequately reflect the real situations - in giving titles to tale types with male and female heroes the points of departure have been different at times. For instance in type AT 313 "The Girl as Helper in the Hero's Flight" it is rather the girl who can be considered the active agent - that is, the real hero of the tale - and the male character emerges in a supporting role (see Lundell 1983: 240241). The aim of the new revision of the international tale-type catalogue has been to consider and correct such gender biases (c.f. Uther 2004: 12) and the title for ATU 313 is simply "The Magic Flight".

Ines Köhler-Zülch (1997: 201-203) has given several examples of how both scholars and publishers of folktales, when discussing the question of the tellers of folktales, tend to direct the results towards an emphasis on male storytellers through their introduction and interpretation of the facts. It seems that such a tendency can also be noted in the case of Estonian material - in the afterword of the Estonian anthology "Eesti muinasjutud" (Estonian Folktales) that provides an overview of all kinds of folktales, Richard Viidalepp, who introduces the tellers of the tales, points out that "it is worth mentioning that men constitute the majority among the storytellers (26 men, 20 women)" (1967: 485). Men are proportionally even more represented in the section of the anthology dedicated to fairy tales (Tale of Magic) ${ }^{1}-16$ tales come from men and 7 from women. The same tales are also presented in a German edition based on this work ("Estnische Volksmärchen", 1980). Even if this statement is based on a (apparently impressionistic) decision deriving from all the manuscript materials that had been studied empirically, the proportion that the compilers themselves have chosen for their collection does not seem to be convincing enough an argument to support the case.

While checking the data regarding the tellers and recorders for the research project "Estonian Fairy Tales" and also when observing the casts of fairy tales the author of the present paper developed the idea to link these data to cast some light on the questions of gender. Several researchers have emphasized that 
tales told by men and women respectively differ in their stylistic colouring and details, rather than in their repertoire (see e.g. Dégh 1995: 69) - thus the difference is 'qualitative'. The data on the storytellers' backgrounds I had at my disposal invited a focus on quantitative data - on observing the genders of the recorders, the tellers and the main characters in combination.

\section{General data}

The analysis is based on fairy tales gathered at the Estonian Folklore Archives of the Estonian Literary Museum (EFA) that have been digitized by the project participants in 1999-2005. The corpus under discussion brings together all manuscripts of Estonian fairy tales from the years 1816-1990 that were discovered in searching the archived collections. The present discussion is based on an article published in Estonian (Järv 2001), but the data on the 2307 tales that were analysed then have been supplemented and now it is the 5550 tales that are included in the corpus of Estonian fairy tales that are considered. As the projects work on fairy tales is almost finished, we can claim, considering the extent of the collections that have been covered, that the present discussion takes into consideration an overwhelming majority of the Estonian fairy tales that have been collected at the archives.

The earlier discussion by the present author covered approximately a half of the material discussed here. As that stage of corpus formation was based on typewritten copies in the EFA made before the project was started, those texts constituted a cross-section of all collections from a somewhat more limited period of time (1870-1940). Thus, the present article offers a ground for comparison to determine if the tendencies observed in that sample will appear valid also in the case of more extensive material.

Figure 1 shows the distribution of the texts over the years since 1855 (more detailed explanations will be provided further in the paper). The archival materials include 264 texts that are undated or are dated incorrectly; in the case of about two thirds of such texts the supposed date of collection could be determined approximately, on the basis of the dates of the neighbouring texts. 


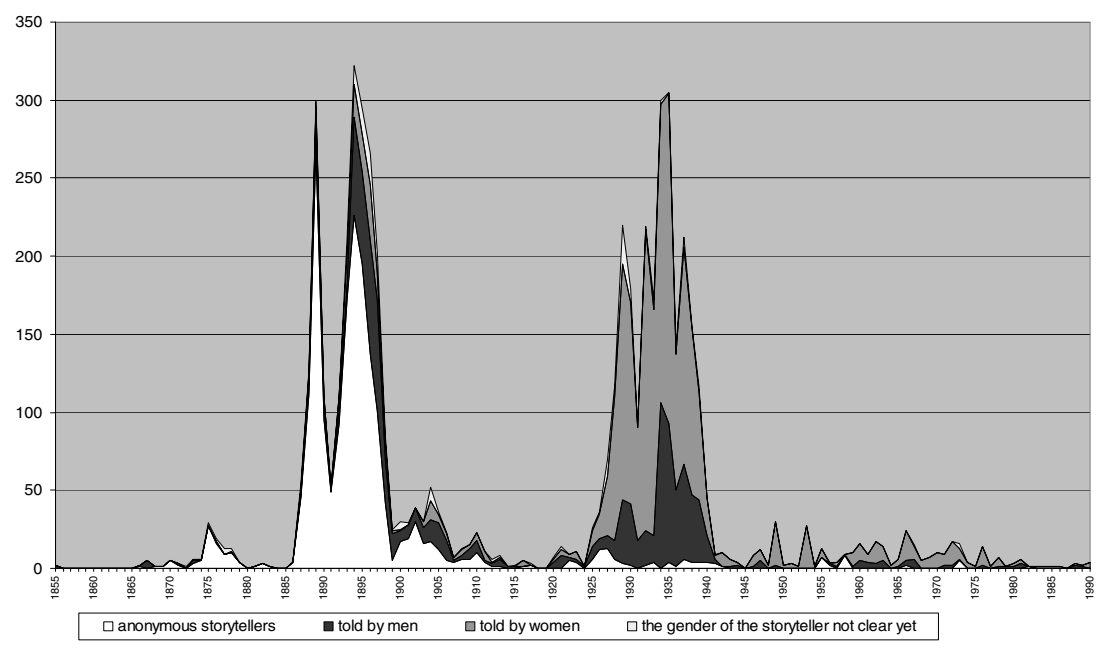

Figure 1. The gender of the tellers of the fairy tales, observed year by year (1855-1990).

Among other things, the figure shows that the arrival of fairy tales at the archives has not been equally intensive through time, the high points of collection (more than 100 texts reaching the archives) being first and foremost the years 1888-1890, 1892$1897 ; 1928-1930$ and $1932-1939$. There was a significant increase in the number of tales after Jakob Hurt's call from the year 1888 "A couple of requests for Estonia's most active sons and daughters". The high point in 1894 (322 texts) coincides with the rise in the enthusiasm for collecting antiquities in the years 1894-1895 when Hurt was preparing to participate in Russia's first Archaeology conference that was to take place in Riga in 1896 (see Põldmäe 1989: 17; Jaago 2005: 52, 62). The ebb in the second decade of the $20^{\text {th }}$ century was caused by World War I and several economic problems; it was followed by particularly intensive collection activities after the Estonian Folklore Archives were founded in 1927. The low rate of collection at the beginning and end of the collection period is understandable - during the early period of folklore collection up to Hurt's call not many fairy tales were collected and starting from the 1940s the number of fairy tale recordings arriving at the archives has dropped again for, on the one hand, the genre itself was increasingly less represented in traditional use and, on the other hand, the research interests of folklore scholars were changing. 


\section{Storytellers}

It appears that during the earlier stage of recording fairy tales the collectors did not consider the persons of storytellers to be particularly important. Therefore, the observation of issues relating to the storytellers' gender tend to be somewhat problematic also in the case of the Estonian material. In the corpus that is available, the first name of the storyteller is known in the case of slightly more than a half (57\%) of texts. However, some information about the gender of the teller is provided also in other ways than just listing the names - so the source of the tale can be noted down as "retold to other people by a 70 years old woman" , "after the dictation of an old woman"3, "heard from the mouth of an old man"4. In the earlier period - marked by the first peak on Figure 1 - it is anonymous texts marked in white that dominate. Only in 1895 did Jakob Hurt first suggest in his public reports - guidelines to his correspondents - that the biographical data on the storytellers be recorded as well (see e.g. Viidalepp 1959: 276); after that the share of the records without the tellers' names starts to diminish, although it does not disappear entirely.

All in all, we know of 2188 tales told by women and 1153 tales told by men, whereas one and the same teller may have told several tales. On the basis of the data regarding the tellers (often only an initial has been given) the gender of the teller could not be determined in the case of 226 texts - on the graph this category makes up the topmost layer of the peaks. At first glance the proportion of the tales told by men seems to be smaller - the tales told by men and women are proportionally divided into one third and two thirds accordingly (see also the distribution of all tales on Figure 2). Satu Apo (1995: 68), however, has found that

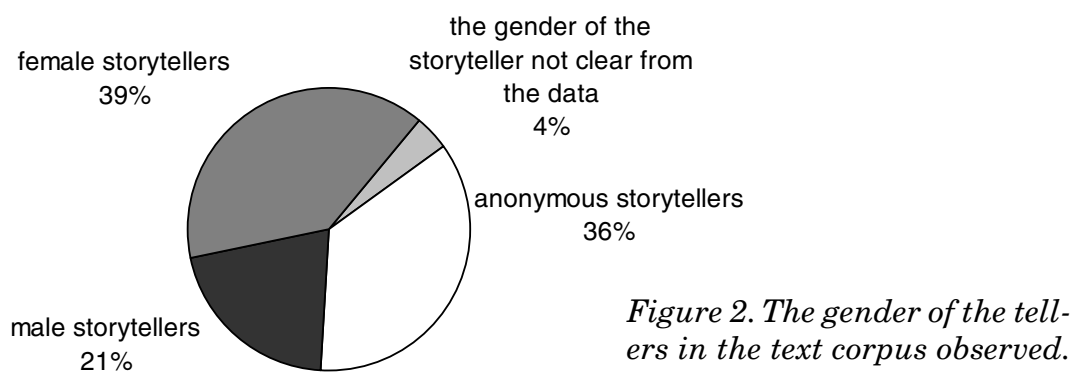


the sample of tales from the Satakunta region in Estonia's neighbouring country of Finland includes $80 \%$ of tales told men and $20 \%$ of tales narrated by women (Apo has analysed 235 texts from the period 1852-1937). In the discussions of gender of the tellers of European fairy tales the proportional divisions have indeed been observed to occur both this way and that. For instance, the Jutland material from the second half of the $19^{\text {th }}$ century that has been analysed by Bengt Holbek mostly (60\%) derives from men, as to other areas of Europe, Holbek gives us examples that either support men's domination or, conversely, contradict it (Holbek 1987: 154-155). Also Linda Dégh's (1984: 332-333) and Ines Köhler-Zülch's (1991: 96-98) works, e.g., refer to contradicting data.

When we consider the division by gender on the annual scale it becomes clear that a change has occured during the period under observation. On Figure 1 the share of fairy tales collected from men is marked in black, the share that comes from women is marked in grey. In the historically earlier part of the corpus male storytellers dominate (at times this 'domination' emerges as the majority of one or two persons per year, though). During the low tide in the collecting activities in the early $20^{\text {th }}$ century the situation appears to have been irregular and starting from 1925 more fairy tales coming from women than those told by men have reached the archives. Figure 3 gives a more detailed survey of fairy tales collected from male and female storytellers.

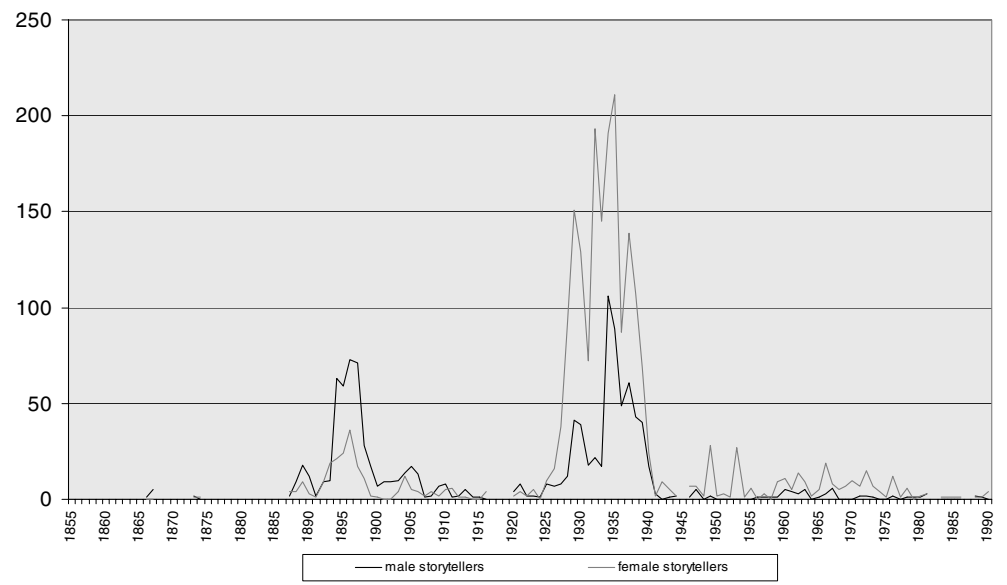

Figure 3. The number of tales collected from men and women, year by year. 
Most of the fairy tales the gender of whose teller is recorded in the data on collection have been collected in the $20^{\text {th }}$ century, but during this period - and thus also within the whole corpus there are more women among the storytellers. The earlier tales have been collected mostly from men; the later ones - from women. The transferring of the tradition of storytelling to women was triggered in Estonia obviously by several reasons, for instance the reduction of tales into children's lore, which means that women have read more - or have had to read more - books of fairy tales. The issue is still not quite settled regarding the earlier material in which the proportion of 'anonymous tellers' is exceedingly high (for instance, one cannot exclude he possibility that women were not - or their social status was not - considered sufficiently important for their names to be noted down.) Still, the proportion of men among the known storytellers seems to indicate that the Estonian fairy tale tradition used to belong to men at the end of the $19^{\text {th }}$ century and was later transferred to women. ${ }^{5}$

The graph on Figure 1 shows that the watershed in the change of tendencies in narrating occurred in the low tide of the incoming fairy tale materials (but maybe also archival material in general) in the second decade of the $20^{\text {th }}$ century. Based on the shift in the gender dominant I have provisionally divided the in two - "the earlier" and "the later" groups, (2720 and 2830 fairy tales, accordingly) - for the purposes of later analysis.

\section{The collectors' possible influence on the material}

The formation of archival materials is, in addition to informants, largely determined by the collectors, and thus also the subjective and objective preferences of folklore collectors have to be takes into account. An objective influence on the results can, for instance, be seen in the fact that men have first and foremost had access to traditionally masculine fields of life (see, e.g., KöhlerZülch 1997: 207). Also in the narrating situations described by Richard Viidalepp, fields that mostly men were in touch with fishing and hunting, night-time minding of the horses and cattle, inns, military service etc. dominate (Viidalepp 1959: 278-283). ${ }^{6}$ It is fairly certain, though, that the fairy tales recorded in Estonia have mostly been jotted down in "artificially created" situations. 
The data regarding collectors of the tales are much more thorough than facts about storytellers themselves; in the same body of texts observed the gender of the collectors of 5202 variants is known (in some cases the gender of the collectors can be guessed with a very high probability on the basis of their professions schoolmaster, joiner etc.) The fairy tale texts in the corpus in the case of which both the gender of the storyteller and that of the collector is known (3228 cases all in all) - tend to demonstrate that it is not only from men that men have heard fairy tales from. Quite to the contrary, it appears that male collectors have collected somewhat more fairy tales from female narrators.

\begin{tabular}{lrr}
\hline & \multicolumn{1}{c}{ male } & \multicolumn{1}{c}{ female } \\
& storytellers & storytellers \\
\hline male collectors (2225 stories collected) & $39,8 \%$ & $60,2 \%$ \\
female collectors (975 stories collected)) & $23,6 \%$ & $76,4 \%$ \\
male \& female collectors (28 stories collected) & $3,6 \%$ & $96,4 \%$ \\
Total & $34,6 \%$ & $65,4 \%$ \\
\hline
\end{tabular}

Such a tendency has been caused by the more numerous later recordings. During the earlier period (up to 1918) nearly all (known) collectors were men - they obtained more than two thirds of their tales from men and less than a third from women. In the later period, when it is mostly women who emerge as storytellers, both men and women have collected over three times more fairy tales from women storytellers than they have from men. Thus the earlier predominance of male storytellers may - yet need not - be caused by the collectors' "filter".

\begin{tabular}{lrr}
\hline $1855-191$ & \multicolumn{1}{l}{ male } & female \\
& storytellers & storytellers \\
\hline male collectors (683 stories collected) & $71,2 \%$ & $28,8 \%$ \\
female collectors (4 stories collected)) & $0 \%$ & $100,0 \%$ \\
Total & $70,7 \%$ & $29,3 \%$ \\
\hline \hline $1919-199$ & male & female \\
& storytellers & storytellers \\
\hline male collectors (1542 stories collected) & $25,9 \%$ & $74,1 \%$ \\
female collectors (971 stories collected)) & $23,7 \%$ & $76,3 \%$ \\
male \& female collectors (28 stories collected) & $3,6 \%$ & $96,4 \%$ \\
Total & $24,8 \%$ & $75,2 \%$ \\
\hline
\end{tabular}

Table 1. The gender of the collectors and storytellers. 


\section{Fairy tales with feminine and masculine plots in the corpus}

Traditionally, scholars have divided fairy tales into those with feminine and masculine plots according to the main character's gender. I have added observations about the narrator's gender to answer the question how the archive materials of Estonian masculine and feminine fairy tales are divided between storytellers of different genders. Bengt Holbek has made a similar division by tale types in his Interpretation of Fairy Tales on the basis of the 758 fairy tales from Evald Tang Kristiansen's collection (Holbek 1987: 162-166).

I considered the main characters of all the fairy tales in the corpus without automatically excluding tales that, according to ATU, belong to the section of fairy tales, yet actually so not seem to belong here due to some of their content characteristics. However, such problematic plots that have two main characters of different genders, e.g most of the variants of the type ATU 327A ("Hansel and Gretel") were left aside. Already Axel Olrik's (1992: 51) laws of the epic drew attention to the fact that in some fairy tales the characters function as twins, as it were, fulfilling one and the same function. Therefore, it is difficult to determine which of them should be considered the protagonist.

At the same time I did not always follow Holbek's classification of the tales into masculine and feminine types, but proceeded from the characters of the Estonian variants. Thus, Holbek labels tale type ATU 720 ("The Juniper Tree") as masculine (apparently the Danish variants resemble the story "Von dem Machandelboom" in the Brothers Grimm collection (KHM 47) in which the hero is a boy), while in the Estonian variants the main character who is persecuted by the step-mother and devoured by the family is usually a girl. Also, for example Holbek names ATU 312 ("Maiden-Killer (Bluebeard)") as masculine, but the present writer sees the tale, at least in the case of Estonian material, as clearly representing "the woman's point of view" etc.

In the material discussed by Holbek $88 \%$ of the tales told by men were masculine and $12 \%$ feminine, whereas in the tales told by women the percentages were $54 \%$ and $46 \%$, respectively (Holbek 1987: 168). The Estonian material of the text corpus gave a quite 


\begin{tabular}{ll}
\hline Stories told by men (1120) & \\
\hline Masculine plot & $81,7 \%$ \\
Feminine plot & $18,3 \%$ \\
\hline
\end{tabular}

\begin{tabular}{lr}
\hline \multicolumn{2}{l}{ Stories told by women (2067) } \\
\hline Masculine plot & $63,0 \%$ \\
Feminine plot & $37,0 \%$ \\
\hline
\end{tabular}

Table 2. Tales with masculine and feminine plots told by men and women.

similar result $-81 \%$ of the variants told by men and $63 \%$ of tales told by women were masculine tales.

I also checked the material for possible indications of the abovementioned temporal watershed to find out if there is a difference between an "earlier" and a "later" tradition. Comparison of analogous numerical data showed that virtually no large change can be observed - in the earlier temporal division the number of tales that have female main characters and are also told by women is higher than the corresponding number in the later division by a 15\% (Figure 4 represents tales with male and female heroes, told by male and female storytellers at different times). Thus we can concede that in the Estonian material the gender division

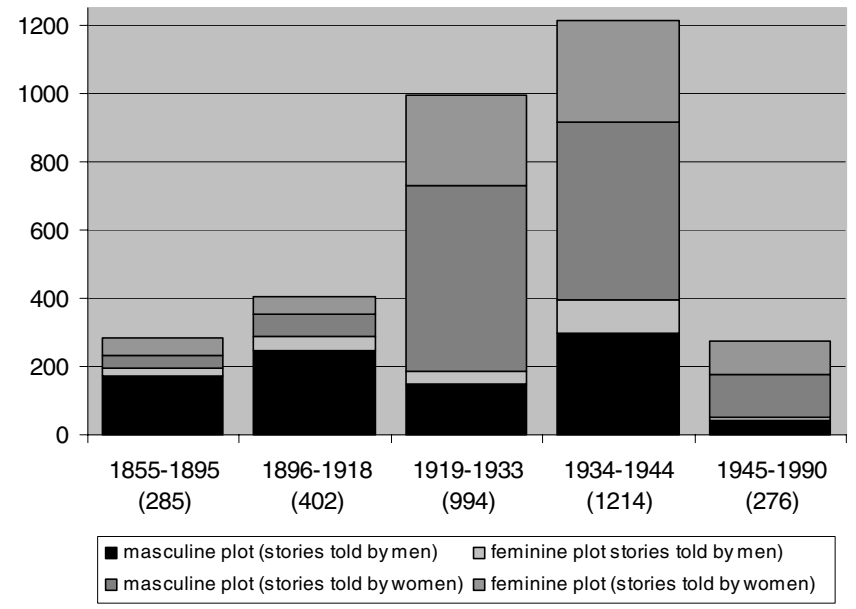

Figure 4. Fairy tales with male and female heroes told by men and women in different periods. 
has remained quite stable during the period under observation, with only a slight tendency towards masculine plots becoming more popular among women.

\section{The tale types' "belonging" to men and women}

On the basis of the data described above I also attempted to discover such tale types in the case of which most of the tellers of the variants would belong to the opposite sex of the tale's main hero. At this point, it has to be taken into account that the typology of Estonian fairy tales can still change to an extent in comparison with the present one. In the framework of the fairy tale project the earlier typological adherence of many texts has already been changed, in some cases it has yet to be specified in the final phase of the project. The following analysis does not cover fairy tales the typological belonging of which is problematic.

Table 3 introduces the tale types in the case of which the number of the storytellers who belong to the opposite gender in comparison with the hero is considerably higher and in which the confidence intervals do not coincide with $95 \%$ likelihood (x). ${ }^{7}$ All such

\begin{tabular}{|c|c|c|c|c|c|c|c|}
\hline \multicolumn{2}{|c|}{ type } & \multicolumn{2}{|c|}{$\begin{array}{l}\text { variants told by } \\
\text { men } / \%\end{array}$} & \multicolumn{2}{|c|}{$\begin{array}{l}\text { variants told by } \\
\text { women } / \%\end{array}$} & \multirow{2}{*}{$\begin{array}{c}\mathrm{M} / \mathrm{F} \\
\mathrm{M}\end{array}$} & \multirow{2}{*}{$\begin{array}{c}x \\
0,433\end{array}$} \\
\hline 449 & The Tsar's Dog (Sidi Numan) & 2 & $11,8 \%$ & 15 & $88,2 \%$ & & \\
\hline 700 & Thumbling & 15 & $22,4 \%$ & 52 & $77,6 \%$ & $\mathrm{M}$ & 0,349 \\
\hline $572^{*}$ & $\begin{array}{l}\text { The Barking Dog's Head, the Striking } \\
\text { Axe, etc. }\end{array}$ & 17 & $24,3 \%$ & 53 & $75,7 \%$ & $\mathrm{M}$ & 0,310 \\
\hline 402 & The Animal Bride & 14 & $26,9 \%$ & 38 & $73,1 \%$ & M & 0,215 \\
\hline 315 & The Faithless Sister & 14 & $28,0 \%$ & 36 & $72,0 \%$ & M & 0,185 \\
\hline 306 & The Danced-out Shoes & 10 & $26,3 \%$ & 28 & $73,7 \%$ & M & 0,184 \\
\hline 461 & Three Hairs from the Devil's Beard & 14 & $29,2 \%$ & 34 & $70,8 \%$ & M & 0,153 \\
\hline 530 & The Princess on the Glass Mountain & 47 & $36,4 \%$ & 82 & $63,6 \%$ & M & 0,104 \\
\hline 314 & Goldener & 24 & $33,8 \%$ & 47 & $66,2 \%$ & M & 0,100 \\
\hline 653 & The Four Skillful Brothers & 5 & $25,0 \%$ & 15 & $75,0 \%$ & M & 0,095 \\
\hline 465 & $\begin{array}{l}\text { The Man Persecuted Because of his } \\
\text { Beautiful Wife }\end{array}$ & 14 & $31,8 \%$ & 30 & $68,2 \%$ & M & 0,080 \\
\hline 302 & The Ogre's (Devil's) Heart in the Egg & 15 & $32,6 \%$ & 31 & $67,4 \%$ & $\mathrm{M}$ & 0,069 \\
\hline 613 & The Two Traveler & 35 & $36,8 \%$ & 60 & $63,2 \%$ & $\mathrm{M}$ & 0,067 \\
\hline 550 & Bird, Horse and Princess & 12 & $31,6 \%$ & 26 & $68,4 \%$ & M & 0,063 \\
\hline 400 & $\begin{array}{l}\text { The Man on a Quest for his Lost } \\
\text { Wife }\end{array}$ & 5 & $26,3 \%$ & 14 & $73,7 \%$ & M & 0,049 \\
\hline 551 & Water of Life & 3 & $23,1 \%$ & 10 & $76,9 \%$ & M & 0,029 \\
\hline 555 & The Fisherman and his Wife & 11 & $32,4 \%$ & 23 & $67,6 \%$ & $\mathrm{M}$ & 0,026 \\
\hline 513 & The Extraordinary Companions & 14 & $34,1 \%$ & 27 & $65,9 \%$ & $M$ & 0,018 \\
\hline
\end{tabular}

Table 3. Tale types included in the corpus, the protagonist of which usually belongs to the opposite gender compared with the storyteller. 
tales have masculine plots, which means that on no occasion did a woman hero "entice" several men to tell her tale. At the same time, this can also result from the fact that more fairy tales in the whole corpus have been told by women.

As becomes apparent, several of the tale-types are characterised by a woman giving advice to the male hero. For instance, in type ATU 402 ("The Animal Bride") the woman hero who appears as an animal gives tips to the hero about how to fulfil different tasks, and later turns into a beautiful spouse. In type ATU 461 ("Three Hairs from the Devil's Beard") the hero learns from the Old Devil's wife where the keys to the gold, silver and other towns are to be found etc. On the basis of these examples the explanation would seem to be easy - as regards several types, women may have preferred to memorise and retell such stories that verify the common belief that "there is a woman behind every successful man".

The supposition is, however, contradicted by several fairly masculine types, for instance ATU 530 ("The Princess on the Glass Mountain"). Also, not all tale types with main heroes that are preferred by women show women in a positive light. For instace in tale type ATU 449 "The Tsar's Dog" (Sidi Numan) that occupies the first position in result of this calculation a woman turns the male hero into a dog and thus the tale, to the contrary, demonstrates the horrid nature of women. In tale type AT 306 ("The Danced-out Shoes") the task of the male protagonist is to detect a vice of women - going out dancing at night, and ATU 315 ("The Faithless Sister") tells the story of a sister who has teemed up with the Evil One.

When the fairy tales are divided into earlier and later groups again, it appears, however, that the earlier narrators of the tales have rather been of the "right" gender - here are either no representatives of the opposite gender among them, or they are very few in number. Thus, most of these types have still been more popular with men in earlier times - for instance, in the earlier period Type ATU 530 has been told by 19 men and only five women, ATU 315 by seven men and two women and ATU 306 by four men and one woman. The same tendency appears in the case of tale type ATU $572^{* 8}$ in the earlier part of the corpus - all 
the six texts derive from men. However, in the 20th century the tellers the same tale have been mostly women.

Another reason that can have caused later popularity of fairy tales among woman storytellers is the texts being published the majority of the tales observed here have also been popular in literature, for example ATU 551 ("Water of Life"), many variants of which in Estonia have been influenced by Juhan Kunder's tale "The Miraculous Mirror" or ATU 653 ("The Four Skilful Brothers") that is known from the collection of Brothers Grimm. Due to the mediation of M. J. Eisen's popular books Type ATU 314 ("Goldener") that contains the earlier type 532 from AT ("I Don't Know") has also gained popularity. In literature, also tale type ATU 700 ("Thumbling") is popular. Let it be mentioned that in Bengt Holbek's terms, it is a children's fairy tale - these are tales that are not full-length fairy tales, but "may end with a happy marriage, but they do not have to" (Holbek 1987: 160-161). It should be remarked that while on the basis of the Jutland material the tellers of this tale have mostly been male (see Holbek 1987: 166), the observed sample shows that in Estonia the tale belonged first and foremost to the repertoire of women. Apparently the reason again lies in the fact that the fairy tale tradition has become lore that is read to children.

A comparison with the results with the analysis carried out four years ago shows that the tendencies observed in the case of more limited material have remained more or less valid also in the case of full material - the relative representation of both male and female storytellers in the Tables and Graphs differ from the earlier observation generally only by a few percentage points. What is different, however, is the top list of "the tales of opposite gender", which stems from a different method of calculating. Also, there is a stronger tencency, as compared to earlier analysis, of women's repertoire acquiring more masculine plots.

All in all, it can be concluded that on the basis of the Estonian archive materials it appears that in earlier times fairy tales have been told first and foremost by men; this, however, can be caused by the fact that almost all of the earlier collectors were men. Also, in earlier times Estonian storytellers preferred mostly stories in which the main character is of the same gender as the storyteller him/herself. Later the situation changed and by the 
$20^{\text {th }}$ century some masculine fairy tales have become more popular among women. In this development, the popularity of the tales in literature and the status of fairy tales as "children's fairy tales" may have played their role, as may the helping role of women characters, typical of certain plots.

\section{Comments}

1 In the following the terms 'fairy tale' and 'tale' are used to denote 'Tale of Magic'.

2 H II 28, $131<$ Äksi - August Mauer (1890).

3 H, Jõgever 1, 26 (101) < Pöide - Villem Mägi (1888).

4 H I 10, 553 (1) < Setu, Pankjavitsa, Tserepi - Friedrich Treijal (1896). It could be supposed that such detailed and evasive expressions can be characteristic of the recorder's own fabulation - for instance, a fairly untraditional fairy tale collected by $\mathrm{H}$. A. Schultz has been described as "a tale told by an eighty years old man" (H III 4, 37 (1) < Koeru - H. Schultz (1890)).

5 Bengt Holbek (1987: 154-157) explained a similar tendency in the Jutland material with the fact that women carry on the waning fairy tale tradition even some time after men have ceased to do that, but Ines Köhler-Zülch has set the general validity of the claim in question altogether (see Köhler-Zülch 1997: 207-208 for details). In any case the proportionally higher share of male narrators in the earlier times could probably also explain the tendencies noted in the texts selected for the anthology Estonian Folktales - most of the texts for this anthology have been selected from earlier collections and thus it is understandable that it was mostly male narrators who should belong to the selection.

6 Of course, the shared tasks of women and get-togethers of young people have also played an important role.

7 Cf. Sarv 2000: 77, note 50. In my earlier discussion (Järv 2001) I observed the types in the case of which the number of the narrator belonging to the opposite sex of the hero was the highest in absolute terms.

8 In this tale "The Barking Dog's Head", in Estonia also under the title "Pleasing the King's Daughter" - see Salve, Sarv 1987: 177) a boy finds objects in the wood that make sounds with the help of which he can make the king's daughter laugh. The type has been adopted only in AarneThompson catalogue of 1961 on the basis of Estonian fairy tales (Rausmaa 1988: 496). 


\section{References}

Apo, Satu 1995. The Narrative World of Finnish Fairy Tales. Structure, Agency, and Evaluation in Southwest Finnish Folktales (FF Communications 256). Helsinki: Suomalainen Tiedeakatemia.

Apo, Satu 1990. Kansansadut naisnäkökulmasta: Suuren äidin palvontaa vai potkut Lumikille? Louhen sanat. Kirjoituksia kansanperinteen naisista. (Suomalaisen Kirjallisuuden Seuran Toimituksia 520). Ed. A. Nenola, S. Timonen. Helsinki: Suomalaisen Kirjallisuuden Seura, pp. 24-35.

$\mathrm{AT}=$ Antti Aarne / Stith Thompson. The Types of the Folktale. A Classification and Bibliography. (FF Communications 184). 2nd rev. Helsinki: Suomalainen Tiedeakatemia, 1961.

ATU $=$ H.-J. Uther, The Types of International Folktales. A Classification and Bibliography. Based on the System of Antti Aarne and Stith Thompson. Part I: Animal Tales, Tales of Magic, Religious Tales, and Realistic Tales, with an Introduction. (FF Communications 284). Helsinki: Suomalainen Tiedeakatemia, 2004.

Dégh, Linda 1984. sub "Erzählen, Erzähler" - Enzyklopädie des Märchens. Handwörterbuch zur historischen und vergleichenden Erzählforschung. Band 4. Herausgeg. K. Ranke. Berlin-New York: Walter de Gruyter, pp. 315-342.

Dégh, Linda 1995. The Nature of Women's Storytelling. Narratives in Society : A Performer-Centered Study of Narration. FFC 255. Helsinki: Suomalainen Tiedeakatemia, pp. 62-69.

Eesti muinasjutud 1967. Koost. V. Mälk, I. Sarv ja R. Viidalepp. Tallinn: Eesti Raamat.

EvM = Estnische Volksmärchen. (Volksmärchen: eine Internationale Reiche). Hrsg. von R. Viidalepp, Redaktion von F. Geißler; Übersetzung von E. Meyer. Berlin: Akademie-Verlag, 1980.

Holbek, Bengt 1987. Interpretation of Fairy Tales. Danish Folklore in a European Perspective. (FF Communications 239). Helsinki: Suomalainen Tiedeakatemia.

Jaago, Tiiu 2005. Jakob Hurt: The Birth of Estonian-language Folklore Research. - Studies in Estonian Folkloristics and Ethnology. A Reader and Reflexive History. Ed. by K. Kuutma and T. Jaago. Tartu: University of Tartu, Estonian Literary Museum, pp. 45-64.

Järv, Risto 2001. Eesti imemuinasjuttude kangelaste, jutustajate ja kogujate soost - Klaasmäel (Pro Folkloristica VIII). Ed. M. Hiiemäe, K. Labi. Tartu: Eesti Kirjandusmuuseum, pp. 28-44.

Köhler-Zülch, Ines 1991. Ostholsteins Erzählerinnen in der Sammlung Wilhelm Wisser: ihre Texte - seine Berichte. Fabula. Zeitschrift für Erzählforschung. 32. Band, pp. 94-118. 
Köhler-Zülch, Ines 1997. Who Are the Tellers? Statements by Collectors and Editors. Fabula. Zeitschrift für Erzählforschung. 38. Band, pp. 199209.

Lovell-Smith, Rose 1999. Feminism and Bluebard. Estudos de Literatura Oral, N 5. Universidade do Algarve, pp. 43-53.

Lundell, Tuborg 1983. Folktale Heroines and the Type and Motif Indexes. - Folklore, vol. 94: ii, pp. 240-246.

Olrik, Axel 1992. Principles for Oral Narrative Research. Bloomington and Indianapolis: Indiana University Press.

Põldmäe, Rudolf 1989. Materjale J. Hurda vanavara kogumise loost. Paar sammukest eesti kirjanduse uurimise teed XII [Zusammenfassung: Materialen zur Sammeltätigkeit Jakob Hurts]. Uurimusi Jakob Hurda 150. sünniaastapäevaks. Tallinn, pp. 10-40, 211-212.

Rausmaa, Pirkko-Liisa 1988. Suomalaiset kansansadut 1. Ihmesadut. (Suomalaisen Kirjallisuuden Seuran Toimituksia 482). Ed.P.-L. Rausmaa. Helsinki: Suomalaisen Kirjallisuuden Seura.

Salve, Kristi; Sarv, Vaike 1987. Setu lauludega muinasjutud. (Ars musicae popularis, [5]). Tallinn: Eesti NSV TA Keele ja Kirjanduse Instituut.

Sarv, Mari 2000. Regilaul kui poeetiline süsteem. (Paar sammukest, XVII. Eesti Kirjandusmuuseumi aastaraamat). Ed. J. Oras, E-H. Västrik. Tartu: Eesti Kirjandusmuuseum.

Stone, Kay 1975. Things Walt Disney Never Told Us. Women and Folklore: Images and Genres. Ed. C. R. Farrer. Prospect Heights, IL: Waveland Press, pp. 42-50.

Viidalepp, R[ichard] 1959. Rahvajutustaja rahva hulgas. Etnograafia Muuseumi aastaraamat. XVI. Tallinn: Eesti Riiklik Kirjastus, lk 275-296. 